\title{
British Criminological Amnesia: Making the Case for a Black and Postcolonial Feminist Criminology
}

\author{
Clare Choak ${ }^{1}$
}

\begin{abstract}
The discipline of Western criminology emerged during the colonial era as a means of controlling the 'other'. Despite its failures in terms of rehabilitation and recidivism, these perspectives have been adopted on a global scale. Crime and punishment have been heavily influenced by these ideas and continue to reproduce them in problematic and pathologising discourses such as the United Kingdom gang agenda. This has positioned young Black men as naturally aggressive, sexual predators and innately criminal. A move towards a British Postcolonial Criminology has received scant attention despite there being a range of global literature which calls for changes to be made to the roots of the discipline. Whilst Black people have been sidelined, stereotyped or ignored, so too have been women, with Black women being noticeably absent. Feminist criminology in Britain has also been criticised for its failure to adequately deal with issues of race. Consequently, drawing on what has been written to further the cause of a Black Feminist Criminology (BFC), this paper argues for the adoption of a Black and Postcolonial Feminist Criminology (BPFC) in the UK whereby issues of race, intersectionality and historical perspectives are central to how we understand crime.
\end{abstract}

Keywords: postcolonial criminology, criminological amnesia, Black and postcolonial feminist criminology, intersectionality, gang agenda

\footnotetext{
${ }^{1}$ The Open University, United Kingdom
} 


\section{Introduction}

The discipline of criminology in Britain and its various areas of debate pays a notable and concerning lack of attention to issues of race and decolonial baggage. This paper builds on these ideas, whilst also considering how racist discourses, which position certain ethnic groups as more criminogenic than others, are built on a history of imperial thought and its continued legacies. There has been a global commitment to the development of a Postcolonial Criminology, so far, however, in the British context at least, such ideas are very much in their infancy demonstrating criminological amnesia in regards to crime and race relations.

This paper calls for a move towards a Postcolonial Criminology in the UK and provides evidence of operational colonial legacies in relation to the contentious gang agenda which positions young Black men as naturally violent, sexual savages and inherently criminal. It will draw on works of Black Criminology and Black Feminist Criminology (BFC) as British Feminist Criminology has barely touched on these ideas. It is argued that, in order to move forward, the development of a Postcolonial Criminology in the UK drawing on a Black and Postcolonial Feminist Criminology (BPFC), which centralise race and intersectionality, is one strategy to reach this goal.

\section{Why the Need for a Postcolonial Criminology?}

If one of the key aims of prison as a form of punishment is to rehabilitate, Western ${ }^{1}$ approaches have been proven to be highly ineffective. This is demonstrated by the increased numbers of those incarcerated, in addition to consistent reoffending rates. The UK has one of the highest imprisonment rates in the West. In England and Wales, prison populations have increased by over two thirds in the past three decades, with almost half of adults reconvicted of another offence within one year of release (Prison Reform Trust, 2019). The ramifications of this are particularly concerning given the over-representation of Black people in stop-and-search statistics, culminating in further arrests and prison sentences. In terms of mass incarceration, links are rarely made to slavery and colonialism despite many arguing that the penal system is The New Jim Crow (Alexander, 2012).

Michael Coyle (2010) has noted how language is used as a basis to justify human suffering, such as slavery, based on positioning certain racial identities as undesirable and thus excluding them from the mainstream; an example of this being the mass incarceration of young Black men. In 
England and Wales, the disproportionality of Black people in prisons is greater than in the United States (Lammy, 2017).

Biko Agozino (2004, p. 345) suggests there is a "conspiracy of silence" around state crime and human rights abuses amongst criminologists, drawing on Stanley Cohen's work (1993) around denials of these abuses of power. For Agozino (2019, p. 13) criminology has served colonialism more than other fields such as the social sciences and humanities, as disciplines such as anthropology have been quicker to acknowledge the relationship between imperialist thought, whereas "control-freak criminologists" have been far more resistant to change. Agozino argues for a Postcolonial Criminology being due, in part, because criminology emerged as a means of controlling the 'other' at the same time as colonialism, which demonises certain groups by positioning them as less lawful than other groups. He objects to the construction of 'the criminal' being rooted in insights which are not based on historical perspectives, with a focus on punishment rather than reparation for past crimes committed by the state, such as transAtlantic slavery, or what he refers to as the African holocaust. Similarly, for Chris Cunneen (2011, p. 249) a postcolonial perspective, which is underpinned by Indigenous criminological thought, is one which acknowledges the impact of colonialism and its continued legacies as "colonization and the postcolonial are not historical events but continuing social, political, economic, and cultural processes". In this sense, he is reiterating that the 'post' in postcolonial does not imply that the legacies of colonialism have somehow been magically resolved, but are instead ongoing. Cunneen and Juan Tauri (2016) argue that the discipline needs to be challenged as it is currently far too complacent and comfortable being rooted in a Western imperial framework.

Tina Patel and David Tyrer (2011) have also highlighted how criminology has a predictable focus on individual responsibility and pathology for explanations of crime, whilst structural issues such as racism and social inequality have been sidelined. The idea of 'poverty as crime' is not readily discussed in criminology textbooks. Consequently, Agozino (2019) suggests that organised crime that concerns human rights issues should be prioritised to make these harms more visible. Classicism emerged at the height of the slave trade, however, such historical links are rarely forthcoming when discussing the founders of criminology. A zemiological approach, as proposed by Steve Tombs and Paddy Hillyard (2007, 2017), aims to acknowledge structural inequalities as well as interpersonal harms 
by reframing crime as harm. This perspective has been developed because many events which cause harm are not defined as crime and/or covered by criminal law. Colonialism and its repercussions have also been routinely dismissed in relation to the emergence of criminological thought. This can be explained, in part, due to the lack of attention given to state crime compared to the emphasis placed on the construction of the criminal as working-class and as a participant in street crime. Postcolonial criminology "craves for a criminology that will continue to remain relevant to the lives of people all over the world regardless of geography, race or ethnicity and social class" (Oriola, 2006, p. 121).

In terms of comprehending why criminology is so Western-centric, its colonisation by 'whitemaleness' has meant that historically scholars of colour have been marginalised, with women more susceptible to silencing than their male counterparts (Potter, 2015, p. 7). Furthermore, as racism is part of the university landscape, this can also result in the exclusion of nonWestern academics (Moosavi, 2018). Kathryn Russell (1992) challenged mainstream criminology and developed Black Criminology as a response, with White Criminology referring to the neglect of gender and racial analysis in criminological debates (Cullen et al., 2019). Kathleen Daly and Lisa Maher (1998, p. 5) note how White Criminology avoids the 'race issue' because of racism in the academy and more widely. The usually unexplored area of whiteness and crime - as White people are viewed as the norm from which other people are judged - requires far more attention to understand the Western dominance of the discipline. There is a lack of critical interrogation of 'whiteness and the criminal justice system' with explanations of how these two intersect with why people commit crime being notably absent, as White people often fail to acknowledge that their identities are part of "racialized structured norms" (Smith, 2014, p. 108). As pointed out by Coretta Phillips and colleagues $(2019$, p. 6), whiteness is rarely dissected in the same way as blackness as a colour-blind approach is often adopted due to the "misguided claim" that invoking race is "profoundly racist" when exploring its relationship with the criminal justice system.

\section{Imperialist Expansion in the UK}

During mass immigration to Britain in the 1950s, blackness was linked to deviance and crime, with such discrimination still being felt by these immigrants' grandchildren, thus continuing the process of marginalisation (Gilroy, 2003). The criminal stereotype of the Black mugger which emerged 
in the 1970 s can be traced back to slavery, colonialism and concerns about immigration. Young people had not become more violent in the decades after the Second World War, but Black youth were particularly demonised, viewed as "folk devils in their own right" against a backdrop of anxieties about declining of morals (Cashmore \& Troyna, 1982, p. 25). Mugging had been part of the UK criminal landscape throughout history according to Geoff Pearson (1983), however, from the 1970s onwards, racist propaganda was used to subjugate Black young people by suggesting a link between violence and race as they became synonymous with anti-social behaviour and crime. The Metropolitan Police's 1972 crime figures focused on the smallest category, robbery and violent theft (also known as mugging). Despite this being less than one percent of London's offences, it attracted the media's attention (Muncie, 1984). Black youth became synonymous with the mugger, who, according to the press, was "unBritish" and consequently conceived as a social problem for not confining themselves solely to an English way of life (Brake, 1985, p. 69). Stuart Hall and colleagues (1978) note how the mugging label was an export from America where the issue had become sensationalised. The authors reveal links between the impact of imperial discourses, politics and society, demonstrating how through public consent the police became more authoritarian towards Black communities. Misrepresented statistics around the issue were interpreted as facts thus fuelling biased perceptions. Although mugging was not a new label, it was nevertheless regarded as a new form of crime, and - against a backdrop of media attention - war was declared on muggers.

The impact of the mugging panic influenced opinions on Black youth, representing them as a "riot mob" (Muncie, 1984, p. 83). Misinformed explanations of the cause of the 1980s riots could be seen as a further example of the stigmatisation of young Black men. The 1981 Brixton and 1985 Tottenham riots in London were underpinned by conflict between the Black community, police and the state, with attempts being made to criminalise resistance to inequalities via the rioter (Osgerby, 1997). A main catalyst for the Brixton riot was unemployment. It was also a protest against the system of oppression that Black youth called 'Babylon'. The Broadwater Farm riot in Tottenham was regarded as the most violent disturbance the country had witnessed and was subsequently met with an unwillingness to accept structural rather than pathological explanations as the root cause. The association of blackness with criminality was gaining momentum, despite the majority being 'respectable' working-class people (Cashmore \& 
Troyna, 1982, p. 64). The propaganda resulted in even heavier policing of communities, with Beatrix Campbell (1993) noting how watching Black men being frisked in the street by White police was reminiscent of slave owners. The Scarman (1981) report, responding to the Brixton riots, claimed prejudice was only a feature of a small minority of police officers and failed to address the accusation of state violence. Paul Gilroy (1982, p. 48) critiqued the left-realist stance on race and crime during this period for failing to acknowledge that Black criminality was being used to promote the nation as "white as snow", in addition to presenting racism as a matter for the individual rather than embedded in UK politics through imperial values. His key claim is that you cannot discuss crime committed by Black people without taking the history of racialisation and the state into consideration. For Phillips and colleagues (2019, p. 13) a "criminological amnesia" exists towards the history of the British Empire and its responsibility for violence and punishment during slavery and colonialism. The authors also note that these debates continue to remain unresolved.

The death of Stephen Lawrence in the 1990s continued to demonstrate the colonial relationship between police and Black communities with botched attempts to prosecute the perpetrators and action being delayed as it was assumed that the racist attack by a group of White youth was a drug deal gone wrong. As a response to the mishandling of the case, in addition to the lack of respect afforded to Stephen's family, the Macpherson (1999) report identified institutionalised racism in the police force, which had failed to provide adequate service to people because of their colour. The report made 70 recommendations, including changing how racist incidents are recorded and prosecuted, as well as drawing attention to stop-and-search policies. It claimed that the police would adopt a zerotolerance policy in regards to racism and that officers would be held more accountable for their behaviour. Given the consistent over-surveillance of Black people evidenced annually via stop-and-search figures, plus their continued over-representation in prison, the extent to which these improvements have been achieved is questionable.

Indeed, according to Sheldon Thomas (2012) little has changed since the recommendations of the Macpherson report as there were fundamental similarities between the London riots in 2011 and those in 1981. It was also the perceived unlawful killing of Mark Duggan (deemed later to be legally lawful) and the lack of support police provided to his family, which led to the disturbances in 2011. The government response was to blame gangs. Their 
accusations cementing Black youth in the public imagination as not only muggers and riot mobs, but 'gangstas' too. This would not have come as a surprise to many, however, given that the former British Prime Minister, Tony Blair, declared that increased gun and knife crime could be attributed to a distinct Black culture (Crime \& Justice, 2007).

\section{Colonial Criminology: Gangs on the Agenda}

The racialised nature of the twenty-first-century gang agenda in Britain demonstrates how anxieties about young people are rooted in imperial discourses, with moral panics continuing to demonise young Black men in particular. This is underpinned by the historic stereotype of the violent criminal and potential rapist, who was viewed as deserving of being lynched (Collins, 2004). Right-wing media continue to present young Black people as violent and racialise gang-related activity (Joseph \& Gunter, 2011). The extent to which gang violence is associated with Black youth has been overstated and serves to alters the behaviour of the public towards these groups. They continue to be regarded as the 'other', as threatening outcasts who are not part of mainstream society. ${ }^{2}$ Such misplaced ideas are, according to bell hooks (2004, p. 27), underpinned by a "biased imperialist white-supremacist patriarchal mass media" that teaches Black men that their place is on the streets. Debates which relate to girls and young women almost exclusively focus on sexual exploitation in the UK, further cementing the aggressive and over-sexed male stereotype (Choak, 2019). It has been noted by Vron Ware (2015) that reports about the rape of White women in the nineteenth century wholly misrepresented the facts. American Ida B. Wells, who was one of the founders of the National Association for the Advancement of Colored People (NAACP), observed that the most difficult part of her work in Britain was convincing people that Black men were not savage beasts. This demonstrates how such discourses were built upon the fears and fictions of White people.

The attribution of the gang label has significant implications for those who are so defined, such as potentially facing a longer prison term by being identified as a gang member. Alpa Parmar (2016, p. 5) also alludes to the fact that the gang is "uncritically utilised in criminology" due to the lack of conversations about race, crime and identity. As Anthony Gunter (2017, p. 208) has pointed out, the UK has witnessed a steady and concerning increase of anti-gang laws over the past decade, including "joint enterprise, specialist gang policing units, gang profiling databases/matrices". Sources 
of police intelligence such as databases are used as a basis to justify the surveillance of gang members and are used to identify and categorise individuals who are thought to be gang-active. The utilisation of databases is questionable given the complexities and impossibility in defining what a gang is. Inclusion within a database can result in young people becoming prime targets for the police. Without their knowledge, they are targeted as 'known gang members'. In some cases, young people may be included in a database without having committed a crime and Judge Iain Hamilton has argued that the courts cannot assess how reliable such police intelligence is (Clarke, 2017, September 20). The use of such databases has been strongly criticised by Amnesty International (2018) for breaching human rights and for wrongly stigmatising innocent people. For example, they highlight that just over three-quarters of those on the gang matrix in the Metropolitan area are young Black men, whereas just over a quarter of those involved in serious youth violence are Black. This is an indication of how numbers of Black gang members have been over-estimated. Whilst not all gangs or gang members are violent, these figures do not add up. Those named on the matrix will also receive more attention from the police which results in further over-zealous policing of Black men.

The emergence of the Joint Enterprise law in the UK has meant that someone only has to be present during a crime, rather than be the instigator of that crime, to be sentenced for murder or serious offences (Metropolitan Police, 2016). They also note that "committing any crime as part of a group or gang may lead to a longer prison sentence when a case goes to court". This law means that it is now more dangerous for young people to be in a group situation when criminal events occur, which plays into the public's fears around young people in public spaces. The Prison Reform Trust (2016) suggest that $\mathrm{BAME}^{3}$ groups are affected disproportionately or targeted by joint enterprise convictions in cases which are assumed to be linked to gang activity. Patrick Williams and Becky Clarke's (2016) research indicates that when gangs were mentioned as part of a joint enterprise case over two-thirds of these cases involved BAME prisoners.

The examples of the gang matrix and Joint Enterprise law link to Cunneen's (2011, p. 262) work on Postcolonial Criminology who says that the offender is racial and individuals are racially criminalised. He cites the work of Frantz Fanon (1967, p. 202) who comments on problems surrounding identity that "not only must the black man be black; he must be black in relation to the white man". In terms of a general lack of 
discussion around race and the gang agenda, it is not possible to discuss the lives of young people from urban deprived areas and their relationship with the criminal justice system without acknowledging the role of race, intersectionality and how dangerous it can be to inhabit black skin. Certain UK criminologists are exacerbating and sustaining the racial stereotypes which are associated with gang culture by refusing to engage in these debates. This is important because the British public imaginary assumes a gang member is a young, Black, and lives in a deprived urban area. As Temitope Oriola (2006, p. 110) points out this then becomes a fact, so rather than using their platform to confront such myths, criminologists "are the guilty party".

Research participants are the experts and hold the knowledge that researchers are seeking. Therefore, greater consideration of how findings may potentially impact on their lives and others is key when carrying out research. For example, Simon Hallsworth and Tara Young (2004) created a model to describe what a gang is, despite categorising groups of young people being a positivist venture. As a result, this has been adopted by policymakers and the police, who now use it as concrete 'proof' someone is in a gang, and to justify the harsher treatment of young people. This has had devasting consequences, particularly for the young Black men who have been incorrectly labelled as gang members. This is at odds with Coretta Phillips' and Ben Bowling's (2003) arguments who suggests that criminological research must not misrepresent the lived experiences of minorities and that researchers must take responsibility for the outcomes.

A lack of consideration of harm also contradicts decolonial ways of carrying out research, such an approach to empirical practice is necessary, because "decolonizationcentricity in methodology" is key to ending "racismsexism-classism" (Agozino, 2019, p. 12). It is about moving away from the idea that research participants are 'subjects', thus creating an imbalance of power. For Linda Smith $(2012$, p. 1) the word research "is probably one of the dirtiest words in the indigenous world's vocabulary" whereby communities have been constructed as 'other'. This rings familiar to Black people in the UK. Consequently, Western researchers must not forget how they have been misrepresented, stereotyped and undermined historically by White researchers. 


\section{Making the Case for a Black and Postcolonial Feminist Criminology}

\section{Black Criminology}

Russell (1992) first identified the need for a Black Criminology as a challenge to White Criminology in order to move beyond the limited perspective that Black people commit more crime than other groups, pointing out that blackness as an ethnicity is not monolithic, and suggesting that whiteness could be studied as part of racial analyses of offending. The discipline had not adequately addressed issues of race, by testing exiting theories rather than developing new ones to understand crime rates, nor had it sufficiently explored the relationship between race and crime which considered the colonial model as proposed by Robert Staples (1973). For Russell (1992, p. 681) Black Criminology should be developed by Black criminologists and then be taken on board by other criminologists. Otherwise, there is a risk of 'ghettoization' which could prevent it from becoming mainstream. She regards the importance of Black Criminology as important as Feminist Criminology, noting how feminist approaches have not accounted for the relationship between race and crime in their analyses. Building on this US approach, Phillips and Bowling (2003) developed their minority perspective in the British context which accounts for a wider range of racial and ethnic identities.

James Unnever and Akwasi Owusu-Bempah (2019) demonstrate why there is still a need for a Black Criminology - because Black people experience racism in different ways than other groups - and acknowledge their long history of racial oppression. Furthermore, existing criminological theories do not do enough in terms of adequately explaining, analysing and theorising the Black experience of racial discrimination which stems from the flow of bad will which has culminated over centuries. The authors also point to the pathological focus on offending, such as weak social bonds, rather than taking into consideration that Black people may struggle to bond with social institutions that are institutionally racist. So, the blame needs to be shifted from the individual and their perceived inadequacy to successfully engage. This links to the idea of lack of integration into White society - which is often used as a way to incorrectly explain conflicts between minorities and police - and the negative othering of ethnic groups. 


\section{Black Feminist Criminology}

In order to make inroads towards a British Postcolonial Criminology, the adaption of a Black Feminist Criminology (BFC) is one strategy which has been mooted. It has now been 30 years since Marcia Rice (1990) proposed a BFC in the UK. She observed that criminology and Feminist Criminology in Britain have both failed to adequately explain the crimes of Black women, and, as result, looking beyond these approaches for the answer is necessary. Since then these discussions have stalled somewhat and as Phillips and colleagues $(2019$, p. 2) have argued, the "feminist struggle in criminology is far from concluded". For Rice (1990) and Ruth Chigwada-Bailey (1997), women of colour and/or women from colonised countries tend to be absent from Feminist Criminology. Black women are regarded as marginal to debates which consequently robs them of power, agency and a voice (Reynolds, 2003). Neither Hall and colleagues (1978) nor Gilroy (1982) dealt sufficiently with gender in their respective analysis. The impact of the policing of muggings on Black women, who were involved in the lives of the men affected, would have been a useful addition to their debates considering that many Black women were victimised by the criminal justice system due to these relationships (Agozino, 1997). Agozino (1997) suggests that - due to the focus on White women and Black men - Black women deserve their own studies to further the decolonisation process. This is due, in part, because when a Black woman is discriminated against it is difficult to know if this is due to her class, gender or race, or if incorrect conclusions have been drawn about her lifestyles and behaviours (Chigwada-Bailey, 1997). The colour of a Black woman's skin clearly has consequences when they engage with the criminal justice system. They are more than twice as likely as White women to be arrested, more likely to be remanded or sentenced to custody than any other women, and are $25 \%$ more likely to receive a custodial sentence than White women (Prison Reform Trust, 2017). Furthermore, Black women in prison encounter hostile and racist environments, their needs go ignored by staff, and they suffer verbal abuse with acts of racism going unchallenged (Sudbury, 2005).

Rice (1990), Agozino (1997) and Chigwada-Bailey (1997) have advocated for an intersectional approach which considers how social factors such as class, gender and race overlap, and also one which takes into account history, economics, plus geographical location. Black feminist praxis is a "social justice project" which rejects an additive model, whereby types of inequalities are tagged on, rather than considered as an interlocking 
process (Collins, 2009, p. 43). As noted by Parmar (2016, p. 1) whilst intersectionality has been recognised in US criminology as a useful perspective, the same cannot be said about the UK context, with discussions about race "being shied away from" serving to "stymie meaningful debate" and failing to advance the field. Importantly, Rice (1990) suggests that a Black Feminist Criminology would allow for consideration of all men and women. When carrying out research with diverse groups, researchers should not need to take on more than one perspective according to different individual identities. Since her time of writing there has been more of a consolidated effort in the US to address these issues of exclusion and marginalisation. Although, whilst there is more discussion of race and intersectionality there is also still some way to go in terms of integration into mainstream ideas (Potter, 2013). Hillary Potter (2006, p. 109) has developed her vision of a Black Feminist Criminology which "incorporates tenets of interconnected identities, interconnected social forces, and distinct circumstances". She argues that it is "bewildering" when criminologists still do not take issues of gender and race into account in terms of analysing arrest records, or consider the ways that criminal justice procedures may differ according to social factors (2013, p. 310). Potter's BFC differs from Rice's BFC model as she draws on Black Feminism, Critical Legal Studies and Critical Race Feminist Theory (CRFT). She uses CRFT rather than Critical Race Theory (CRT) due to the exclusion of women's experiences within CRT, which Adrien Wing (2003) suggests has made women of colour voiceless. CRT is rooted in the idea that racism is a normal part of society and that the legal system does not treat people equally according to race. For Potter (2006, p. 107) "BFC can advance future theorizing, research and policy" and has the potential to be applied not only to Black women but other women, including White women, and marginalised men.

\section{Black and Postcolonial Feminist Criminology}

A Black and Postcolonial Feminist Criminology (BPFC) is proposed which draws on BFC models and is inclusive of all identities, concurring with Rice (1990) and hooks (2015), who suggest that feminism should be for everyone. It takes a Black and postcolonial feminist perspective which emphasises race, intersectionality, the legacies of colonialism, and the importance of inclusivity given the exclusionary practices of White feminism and White criminology. The term postcolonial has been included in the title because whilst Black feminist praxis is concerned with the history of imperialism and 
its legacies - it seemed pertinent to highlight the colonial past of the British Empire. The rejection of White feminism and White criminology demands an alternative approach and a different way of viewing the world.

There is a need for a BPFC because a major criticism of feminism is the accusation of privileging the voice of White women by claiming to speak for all women, thus neglecting the diversity of classed and raced identities. White feminism claimed there was one sisterhood which normalised whiteness and excluded others by failing to account for racial difference and assuming there is a singular unifying identity. When using the term White feminism, the author defers to Razia Aziz (1997, p. 70) who suggest that she does not "mean any feminism espoused by white feminists. I refer, rather, to any feminism which comes from a white perspective, and universalizes it". Whilst feminism is focused on decentring gendered knowledge production it has been criticised for not prioritising or centralising race in the same way. For Smith (2012, p. 45), this form of feminism conforms to "some very fundamental Western European world views, value systems and attitudes towards the Other". Ware (2015) explains this by suggesting that because fighting gender oppression is the central preoccupation, feminists may not recognise that their behaviours in terms of race can be oppressive due to White privilege. With this in mind, it is important to note that Black feminist praxis was not solely borne out of a response to White feminism, as it is not simply a critique of the centre, rather it is "radically generative", otherwise it takes away its agency and independent thought (Ali, 2019). She also observes that Black feminist praxis "has always engaged in questions looking back, forward and sideways", and part of this is an acknowledgement of the impact and legacies of a colonial past and how this operates to preside over the current state of racism and race relations. She also notes how Black feminist frameworks support "postcolonial analyses which insist on historicising the present" as combining the two allows for connections to be made across disciplines underpinned by the acknowledgement of global relations of power (Ali, 2009, p. 79). This approach goes some way to address the criminological amnesia which is present in British criminology in terms of its failure to take a historical perspective to issues such as crimes of the powerful.

\section{Doing Decolonial Work}

It is worth mentioning that decolonisation has its critics, as in the UK, for example, it has recently become somewhat of a buzzword, particularly in 
terms of decolonising universities and the accompanying curriculum. With this in mind, Brendon Barnes (2018, p. 382) suggests that "for some, decolonisation is a call to purge a discipline of Western thought [...] and for others, it is to give voice to the marginalised. For others, it is a passing fad, a recycled set of ideas that have very little critical bearing on the critical work that needs to be done". In tandem to this, Eve Tuck and Wayne Yang (2012) have argued that decolonisation should not just be a metaphor which is simply tagged onto a broad range of issues. That said, this does not mean that work towards a Postcolonial Criminology - by way of adopting a BPFC - should be discouraged. There is no quick fix and commitment is required in terms of addressing and moving forward from hundreds of years of violence and crime carried out by the state.

Tauri (2018) observes how Western criminologists have been largely unaffected by the body of work which calls for a Postcolonial Criminology. However, this urgency to move away from criminology in its current form appears to be falling on deaf ears, particularly in the UK context. This should not come as a surprise. As Agozino (2019, p. 18) notes: those who "genuinely oppose decolonization are the ones who make decolonization inevitable". Drawing on Audrey Lorde's (1984) work, The Master's Tools Will Never Dismantle the Master's House, whereby she notes that these tools will never enable genuine change, Tauri shows why a new approach is needed to tackle a Western-centric discipline. Russell (1992, p. 675) has stated that she sees no reason why Black Criminology should not be embedded in mainstream criminology. If it is not, there will be a "theoretical timewarp" and questions would be asked about the "integrity" of the discipline. However, given the lack of interest in these issues compared to other fields in the social sciences and the arts, this is not something which will be without its challenges. In order to establish more Black scholars into the discipline, there needs to be more encouragement of Black students within the university environment to continue their education and pursue study at the doctoral level. With this in mind, exclusion rates in UK schools are three or four times higher for African Caribbean children than other groups (Timpson, 2019) and in the university context, there is a 26\% Black attainment gap (NUS, 2020). These societal issues, which are underpinned by institutional racism, would need to change for there to be more Black criminologists. If criminology is framed by 'whitemaleness' (Potter, 2015, p. 7) this could also be one reason why students are not developing further within the discipline, both in terms of their gendered and raced identities. Agozino (2010, p. xii) argues that in 
terms of working towards a solution, "rather than distort the nature of imperialism, this insight should encourage criminologists to devote at least one chapter in their fat textbooks to crimes of imperialism which account for the most robbery, rape, homicide and other forms of state violence around the world". Potter's (2006) version of BFC has been presented by Pamela Ugwudike $(2015,2017)$ within university-level criminology textbooks. This is a positive sign that these ideas could begin to demand more attention in the UK and potentially become part of mainstream perspectives.

As there are currently not enough scholars of colour and/or those from colonised countries to take on White criminology it should not only be their responsibility within the discipline to challenge and address these issues (Daly \& Maher, 1998). However, this work must be carried out with caution and in a way which ensures that White voices do not become privileged during this process. White scholars should reflect on their motivations for getting involved in such movements whilst simultaneously acknowledging the role of their White ancestors in the processes of colonialism in their respective countries. For the author, as a White female academic in a coloniser country, it is about asking questions such as 'Is it my place to be doing this work?' and, if so, 'How can I involve myself in the struggle without serving to replicate colonial practices?'. As Rachel Liebert (under review, p. 3) rightly points out "white women and coloniality are inextricably linked; feminism and decolonisation are inextricably linked" but these White bodies betray us and cannot be separated from history because they are inscribed with our ancestors' past. Ultimately it is about acknowledging the British Empires' multiple forms of violent imperial history, and its legacies, and reconciling this with one's positionality to decolonising work. Furthermore, Walter Mignolo (2014, p. 589) has warned that scholars must not do so by enacting "rewesternization disguised as dewesternization or decoloniality". Also, it is vital to acknowledge those whose commitment to fighting injustice created the spaces to have these debates, to each of you I am indebted. As Ericka Huggins (2019) has observed, drawing on Vincent Harding, "When you know, you owe".

\section{Conclusion}

This paper argues that, within Britain, there exists criminological amnesia about the discipline's roots in imperial discourses. A Black and Postcolonial Feminist Criminology is one strategy to address a field which has sidelined and consequently misunderstood Black people, women, and in particular 
Black women. It is imperative that the history of slavery and colonialism is acknowledged and deconstructed within the field. This is in addition to addressing the failures of White Feminist Criminology to make headway in these areas. The example of the UK's gang agenda was drawn upon in order to demonstrate how this is a colonial project which positions young Black men in derogatory ways and which can operate to negatively determine their futures. Drawing on existing Black Feminist Criminology frameworks, the paper proposes the development of a Black and Postcolonial Feminist Criminology which is inclusive and can be applied to all identities. It highlights the history of British colonialism, its continuing impact on contemporary policing and Black communities, as well as supporting an intersectional framework to understand multiple identities and potential forms of interlocking oppressions. A move towards addressing imperial baggage cannot occur against a backdrop of the erasure of the British Empire's history and its responsibility for inequalities, violence and racism.

\section{References}

Agozino, B. (2019). Humanifesto of the decolonization of criminology and justice. Decolonization of Criminology and Justice, 1(1), 5-28.

Agozino, B. (2010). What is criminology? A control-freak discipline! African Journal of Criminology and Justice Studies, 4(1), i-xx.

Agozino, B. (2004). Imperialism, crime and criminology: Towards the decolonisation of criminology. Crime, Law \& Social Change, 44, 343358.

Agozino, B. (1997). Black women and the criminal justice system: Towards the decolonisation of victimisation. Aldershot, England: Ashgate.

Alexander, M. (2012). The New Jim Crow: Mass incarceration in the age of colorblindness. New York, NY: The New Press.

Ali, S. (2019). Black and postcolonial feminist connections. Address given at the re-launch of the Race, Ethnicity and Postcolonial Studies Research Group (REPS) at the Department of Sociology, held on October 16 at the London School of Economics.

Ali, S. (2009). Black feminist praxis: Some reflections on pedagogies in higher education. Race, Ethnicity and Education, 12(1), 79-86.

Ali, S. (2007). Feminism and postcolonial knowledge/politics. Ethnic and Racial Studies, 30(2), 191-212.

Amnesty International (2018). Trapped in the matrix. Available at https://www.amnesty.org.uk. 
Aziz, R. (1997). Feminism and the challenge of racism: Deviance or difference? In H. S. Mirza (Ed.) Black British feminism: A reader (pp. 70-80). London, UK: Routledge.

Barnes, B. R. (2018). Decolonising research methodologies: Opportunity and caution. South African Journal of Psychology, 48(3), 379-387.

Brake, M. (1985). Comparative youth culture. London, UK: Routledge.

Campbell, B. (1993). Goliath: Britain's dangerous places. London, UK: Methuen.

Cashmore, E., \& Troyna, B. (1982). Black youth in crisis. London, UK: Allen \& Unwin.

Chiwada-Bailey, R. (1997). Black women's experience of criminal justice: A discourse on disadvantage. Winchester, UK: Waterside Press.

Choak, C. (2019). Young women on road: Femininities, race and gangs in London. Unpublished doctoral dissertation. University of East London, UK.

Clarke, B. (2017, September 20). Death knell for police gang lists. Available at https:// sitesofresistance.org.

Cohen, S. (1993). Human rights and crimes of the state: The culture of denial. Australia \& New Zealand Journal of Criminology, 26, 97-115.

Collins, P. H. (2009). Black feminist thought: Knowledge, consciousness, and the politics of empowerment (2nd ed.) New York, NY: Routledge.

Collins, P. H. (2004). Black sexual politics: African Americans, gender and the new racism. New York, NY: Routledge.

Coyle, M. J. (2010). Notes on the study of language: Towards a critical race criminology. Western Criminology Review, 11(1), 11-19.

Crime \& Justice (2007). Racism and criminal justice. Available at https://www.crimeandjustice.org.uk.

Cullen, F. T., Chouhy, C., Butler, L., \& Lee, H. (2019). Beyond white criminology. In J. D. Unnever, S. L. Gabbidon, \& C. Chouhy (Eds.) Building a Black criminology: Race, theory and crime (pp. 45-76). New York, NY: Routledge.

Cunneen, C. (2011). Postcolonial perspectives for criminology. In M. Bosworth, \& C. Hoyle (Eds.) What is criminology? (pp. 249-266). Oxford, England: Oxford Scholarship Online.

Cunneen, C., \& Tauri, J. (2016). Indigenous criminology. Bristol, UK: Policy Press.

Daly, K., \& Maher, L. (1998). Criminology at the crossroads: Feminist readings in crime and justice. Oxford, UK: Oxford University Press. 
Fanon, F. (1967). Black skins, white masks. New York, NY: Grove Press.

Gilroy, P. (2003, January 8). A new crime, but the same old culprits. The Guardian. Available at https://www.theguardian.com.

Gilroy, P. (1982). The myth of black criminality. Socialist Register, 19, 46-56. Gunter, A. (2017). Race, gangs and youth violence: Policy, prevention and policing. Bristol, UK: Policy Press.

Hall, S., Roberts, B., Clarke, J., Jefferson, T., \& Critcher, C. (1978). Policing the crisis: Mugging, the state, and law and order. London, UK: Macmillan.

Hallsworth, S., \& Young, T. (2004). Getting real about gangs. Criminal Justice Matters, 55(1), 12-13.

hooks, b. (2015). Feminism is for everybody: Passionate politics. New York, NY: Routledge.

hooks, b. (2004). We real cool: Black men and masculinity. New York, NY: Routledge.

Huggins, E. (2019). Radical commitments: The life and legacy of Angela Davis. Available at https://www.radcliffe.harvard.edu.

Joseph, I., \& Gunter, A. (2011). What's a gang and what's race got to do with it? Available at http://www.runnymedetrust.org.

Lammy, D. (2017). The Lammy review: An independent review into the treatment of, and outcomes for, Black, Asian and Minority Ethnic individuals in the criminal justice system. Available at https://www.gov.uk.

Liebert, R. (under review). Whiteness as sickness: Decolonising psychology through uprooting Whiteness and reviving the flesh.

Lorde, A. (1984). Sister outsider. London, UK: Penguin.

Macpherson, W. (1999). The Stephen Lawrence Inquiry. Available at https://www.gov.uk.

Metropolitan Police (2016). Consequences and the law. Retrieved January 3, 2020 from http://safe.met.police.uk.

Mignolo, W. D. (2014). Spirit out of bounds returns to the East: The closing of the social sciences and the opening of independent thoughts. Current Sociology Monograph, 62, 584-602.

Moosavi, L. (2018). Decolonising criminology: Syed Hussein Alatas on crimes of the powerful. Critical Criminology, 27(2), 229-242.

Muncie, J. (1984). The trouble with kids today. London, UK: Hutchinson \& Co. 
NUS (2020). Black attainment gap. Available at https://www.nus.org.uk.

Oriola, T. B. (2006). Biko Agozino and the rise of post-colonial criminology.

African Journal of Criminology and Justice Studies, 2(1), 104-131.

Osgerby, B. (1997). Youth in Britain since 1945. Oxford, UK: Wiley-Blackwell. Parmar, A. (2016). Intersectionality, British criminology and race: Are we there yet? Theoretical Criminology, 21(1), 1-11.

Patel, T. G., \& Tyrer, D. (2011). Race, crime and resistance. London, UK: Sage.

Pearson, G. (1983). Hooligan: A history of respectable fears. London, UK: Macmillan.

Phillips, C., \& Bowling, B. (2003). Racism, ethnicity and criminology: Developing minority perspectives. British Journal of Criminology, 43(2), 269-290.

Phillips, C., Earle, R., Parmar, A., \& Smith, D. (2019). Dear British criminology: Where has all the racism gone? Theoretical Criminology, 1-20. doi.org/10.1177/1362480619880345

Potter, H. (2015). Intersectionality and criminology: Disrupting and revolutionizing studies of crime. Oxon, UK: Routledge.

Potter, H. (2013). Intersectional criminology: Interrogating identity and power in criminological research and theory. Critical Criminology, 21, 305-318.

Potter, H. (2006). An argument for Black Feminist Criminology: Understanding African American women's experiences with intimate partner abuse using an integrated approach. Feminist Criminology, $1(2), 106-124$.

Prison Reform Trust (2019). Prison: The facts Bromley Briefings 2019. Available at http://www.prisonreformtrust.org.uk.

Prison Reform Trust (2017). Counted out: Black, Asian and minority ethic women in the criminal justice system. Available at http://www.prisonreformtrust.org.uk.

Prison Reform Trust (2016). Joint enterprise: Righting a wrong turn? Report of an exploratory study. Available at http://www.prisonreformtrust.org.uk.

Reynolds, T. (2003). Relations between Black female researchers and participants. In T. May (Ed.), Qualitative research in action (pp. 300310). London, UK: Sage. 
Rice, M. (1990). Challenging orthodoxies in feminist theory: A black feminist critique. In L. Gelsthorpe \& A. Morris (Eds.) Feminist perspectives in criminology (pp. 57-69). Buckingham, UK: Open University Press.

Russell, K. K. (1992). Development of a black criminology and the role of the black criminologist. Justice Quarterly 9(4), 667-683.

Scarman, Lord (1981). The Brixton disorders. London, UK: HMSO.

Smith, J. M. (2014). Interrogating whiteness within criminology. Crime \& Deviance, 8(2), 107-118.

Smith, L. T. (2012). Decolonizing methodologies (2nd ed). London, UK: Zed Books.

Staples, R. (1973). What is Black sociology? Toward a sociology of Black liberation. In J. Ladner (Ed.) Death of White sociology (pp. 161-172). New York, NY: Random House.

Sudbury, J. (2005). "Mules", “yardies”, and other folk devils: Mapping crossborder imprisonment in Britain. In J. Chinyere Opara \& J. Sudbury (Eds.) Global lockdown: Race, gender and the prison industrial complex (pp. 167-184). New York, NY: Routledge.

Tauri, J.M. (2018). The master's tools will never dismantle the master's house: An Indigenous critique of criminology. Journal of Global Indigeneity, 3(1), 1-18.

Timpson (2019). Timpson review of school exclusions. Available at https://assets.publishing.service.gov.uk.

Thomas, S. (2012). Revisiting Brixton: The war on Babylon 1981. In D. Briggs (Ed.) The English riots of 2011: A summer of discontent (pp. 111124). Winchester, UK: Waterside Press.

Tombs, S., \& Hillyard, P. (2017). Social harm and zemiology. In A. Liebling, S. Maruna, \& L. Mcara (Eds.) The Oxford handbook of criminology (pp. 284-305). Oxford, UK: Oxford University Press.

Tombs, S., \& Hillyard, P. (2007). From "crime" to social harm? Crime, Law \& Social Change, 48, 9-25.

Tuck, E., \& Yang, K. W. (2012). Decolonization is not a metaphor. Decolonization, Indigeneity, Education \& Society, 1(1), 1-40.

Ugwudike, P. (2017). Gender and feminist criminology. In S. Case, P. Johnson, D. Manlow, R. Smith \& K. Williams (Eds.) Criminology (pp. 284-308). Oxford, England: Oxford University Press.

Ugwudike, P. (2015). An introduction to critical criminology. Bristol, UK: Policy Press. 
Unnever, J. D., \& Owusu-Bempah, A. (2019). A black criminology matters. In J. D. Unnever, S. L. Gabbidon \& C. Chouhy (Eds.) Building a Black criminology: Race, theory and crime. New York, NY: Routledge.

Ware, V. (2015). Beyond the pale: White women, racism and history. London, UK: Verso.

Williams, P., \& Clarke, B. (2016). Dangerous associations: Joint enterprise, gangs and racism. Available at https://www.crimeandjustice.org.uk.

Wing, A. K. (2003). Critical race feminism. New York, NY: New York University Press. 


\section{Endnotes}

1 I defer to Suki Ali's (2007, p. 197) use of 'Northern centres of knowledge production' to define 'Western'.

2 An empirical discussion of the racialised gang agenda can be found in Choak (2019).

3 The term BAME is used here as this is the terminology used by the authors. 